СТУДИЈЕ И ЧЛАНЦИ

UDC 821.163.41.09 Petrović Njegoš P. II

050.8:81/82(497.113)NJEGOŠEV ZBORNIK MATICE SRPSKE https://doi.org/10.18485/ms_zmskij.2021.69.1.1

Др Горан М. Максимовић

\title{
ЊЕГОШЕВО ДЈЕЛО У ЊЕГОШЕВОМ ЗБОРНИКУ МАТИЦЕ СРПСКЕ
}

(Њеїощев зборник Майице срйске. Гл. и одг. уредник академик Александар Младеновић (број 1/2010) и академик Миро Вуксановић (бројеви 2/2014, 3/2018, 4/2020). Нови Сад: Матица српска, 2010-2020, ISSN 1821-4843)

У огледу су анализирани прилози посвећени истраживању књижевног дјела, владарске дјелатности и личности Петра II Петровића Његоша (1813-1851), који су објављени у четири броја Њеїощевой зборника Майице срйске (1/2010, 2/2014, 3/2018, 4/2020). Анализирани прилози су типолошки разврстани на теолошко-философске, историографске, књижевноисторијске, компаративне, историјско језичке, културолошке, лингвостилистичке и текстолошке огледе. При томе је показано да су представљени огледи отворили методолошки разнолике просторе истраживања који нам помажу да Његошево доба, дјело и личност сагледамо из савремене перспективе.

Кључне ријечи: теологија, философија, историја, књижевна историја, компаративистика, историја језика, лингвостилистика, културологија, текстологија.

1. Иницијатива за оснивање Његошевог одбора Матице српске покренута је 2005. године. Предлог су поднијели: академик Миро Вуксановић, академик Радомир В. Ивановић и проф. др Мило Ломпар. Матица српска је основала Његошев одбор 2006. године, а за председника је именован архиепископ цетињски и митрополит црногорско-приморски, преосвећени Амфилохије Радовић (1940-2020). Његошев одбор је у оквиру свог плана рада одлучио да сваке треће године приређује научни скуп посвећен Његошевом дјелу, те да покрене Њеїощев зборник Майице срйске са циљем да афирмише и објављује нова научна истраживања посвећена дјелу Петра II Петровића 
Његоша (1813-1851). Први научни скуп организован је 2009. године, а први број Њеїощевоі зборника Майице срйске изашао је 1/2010. године. До данас су организована укупно четири научна скупа и објављена су укупно четири броја ове научне публикације: поред наведеног броја 1/2010. године, објављени су и број 2/2014, број 3/2018. и број 4/2020. Главни и одговорни уредник броја 1/2010. био је академик Александар Младеновић, од броја 2/2014. дјелатност главног уредника Њеїощевої зборника Майище срйске преузео је академик Миро Вуксановић.

2. Први број Њеїощевог зборника Майице срйске сачињен је од радова који су изговорени на првом научном скупу Дело Пейра II Пейровића Њеіоща у организацији Његошевог одбора Матице српске. Одржан је у Матици српској 20. и 21. марта 2009. године, а председник Одбора научног скупа био је академик Светозар Кољевић. У уводном дијелу Њеїощевог зборника Ма-

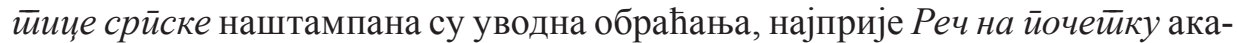
демика Мира Вуксановића, а затим и поздравна слова на отварању научног скупа: председника Матице српске, академика Чедомира Попова и Његовог преосвештенства, епископа бачког г. Иринеја. Након тога је уврштено деветнаест радова који су из различитих преспектива сагледали Његошево доба, дјело и личност, а које можемо посматрати кроз три скупине: културолошку, књижевноисторијску и историјско језичку. Прву скупину засновану на културолошком приступу чине огледи Матије Бећковића, Светозара Кољевића, Мира Вуксановића, Богољуба Шијаковића, Јована Стриковића и Саве Дамјанова. Другу скупину чине књижевноисторијске расправе Душана Иванића, Наде Милошевић Ђорђевић, Снежане Самарџије, Љиљане Пешикан Љуштановић, Младена Шукала, Владимира Осолника, Јована Делића, Горана Максимовића и Весне Вукићевић Јанковић. Трећу скупину чине историјско језичке расправе Александра Младеновића, Мата Пижурице, Бранислава Остојића и Драгане Мршевић Радовић.

На крају првог броја Њеїощевоі зборника Майице срйске штампани су различити прилози, документи, фотографије, који свједоче о оснивању Његошевог одбора Матице српске и одржавању првог научног скупа посвећеног Његошевом дјелу. На крају је штампан In memoriam академика Александра Младеновића (1930-2010), који је преминуо 6. априла 2010. године, а написао га је Мато Пижурица, као ученик и дугогодишњи сарадник академика Младеновића.

2.1. У уводној Речи на йочет̄ку, академик Миро Вуксановић је указао на разлоге покретања Њеі̄ощевої зборника Майице срйске као једанаестог по реду научног зборника ове најстарије српске културне и научне институције, која је основана у Пешти 1826. године. Најважнији разлог је величина Његошевог дјела и личности, а други такође битан разлог садржан је у чињеници да је Његош успоставио чврсте везе са Матицом српском. Први приказ о Његошевој књизи Пустиињак иеейињски написао је Теодор Павловић 
у Лет̄ойису 1834. године, а први Његошев прилог у Летиойису објављен је 1837. године и представља оду испјевану у част српског пјесника и архимандрита Лукијана Мушицког. Већ наредне 1838. године, Летиойис је из Сарајлијине Пјеваније ирноїорске и хериеі̄овачке (1833), објавио Његошеву прозну алегорију Сан на Божић. Његош је постао члан Матице српске 1845. године, а Библиотека Матице српске посједује у свом фонду сва прва издања Његошевих дјела. Године 2004. Матица српска је примила легат Владимира Отовића у коме се налази ,,јединствена збирка књига, часописа, чланака и других ствари о Његошу“ (ВуксАновић 2010: 7), захваљујући којима је постала јединствени извор за проучавање бројних аспеката Његошевог дјела. Уз све то, Матица српска је објавила више издања Његошевих дјела, а у Матичиним зборницима и публикацијама објављено је мноштво прилога о Његошу. Све су то, како наглашава Вуксановић, „били поводи да Матица српска оснује Његошев одбор са задатком да брине о систематском проучавању Његошевог дела“" (ВуксАновит 2010: 8).

У поздравном слову академика Чедомира Попова, које је изговорено на отварању првог научног скупа, такође је указано на нераскидиве и драгоцјене везе владике црногорског Петра II Петровића Његоша и Матице српске. При томе је посебно наглашено да су се и „Матица српска и велики Владика, пустињак Цетињски, самим Божијим послањем вероватно, нашли на сцени историје српског народа у време када су му били најпотребнији, као водећа културна институција и као личност поете мислиоца која ће га надахнути најплеменитијим националним осећањима“" (Попов 2010: 9).

У поздравном слову преосвећеног владике бачког Иринеја Буловића, указано је на значај Његошеве појаве, најизразитије послије светога Саве, а по „количини оспоравања“ можда и изнад светога Саве (Буловић 2010: 11). Док су Сави Немањићу оспоравани величина и значај, светост и историјска улога, у Његошевом случају отишло се још даље, па му је додатно оспораван и „национални идентитет“, као и „православни садржај“ теолошких, космолошких и антрополошких идеја које је износио у својим дјелима, а највише у спјеву Луча микрокозма. Буловић указује на репрезентативне примјере из Горской вијенца, Лажної цара Шћейана Малої и других дјела да би показао колико су та оспоравања неоснована. Осврнуо се и на погрешке у појединим расправама посвећеним Његошевом дјелу, попут запажене студије Исидоре Секулић, али и на свијетле примјере правилног читања и тумачења тог дјела, какво проналазимо у студији Релиїија Њеїощева владике Николаја Велимировића.

2.2. Културолошке студије посвећене Његошевом дјелу отвара оглед академика Матије Бећковића Њеїощ нащ савременик. На основу драматизације Горскої вијенца коју је Бећковић урадио у сарадњи са Бориславом Михајловићем Михизом, а коју је режирала Вида Огњеновић у Народном позоришту у Београду 1980. године, указано је на савременост овог најзначајнијег Његошевог дјела и одличан пријем код позоришне публике. Потом 
је кроз бројне примјере из стихова, међу којима је нарочито упечатљиво значење стиховане Његошеве лозинке „Нека буде што бити не може“, указано на непосредну савремену актуелност овога писца и његовог дјела у посљедњим деценијама 20. и на почетку 21. вијека. У расправи академика Светозара Кољевића О Њеїощевом хумору указано је на бројне примјере комичног и смијеха у Горском вијениу и Лажном изару Шћейану Малом. Показано је како се тај смијех остварује у различитим умјетничким видовима, од језичких смјехотворних формула, преко комичних заплета, до комичне карактеризације јунака. Упечатљиве су бројне ситуације у којима се појављују Вук Мићуновић и Вук Мандушић, хоџа Брунчевић, војвода Драшко, баба вјештица и поп Мићо, игуман Стефан и Теодосије Мркојевић, у којима се смјехотворно подједнако остварује и за приказивање различитих „сцена ужаса“, културолошких разлика, али и препознавање разноликих животних ситуација. Смјехотворно у Горском вијениу Кољевић доводи у везу са народном традицијом и смјеховном културом, док се Лажни цар Шћейан Мали више посматра у контексту политички интонираних комедија европске пародичне традиције, од хомеровског Боја жаба и мищева, као пародије Илијаgе, па све до Поупове Оймище коврие (1712). У расправи академика Мира Вуксановића Крсти Обраяов вище Горе Црне указано је на вишезначну симболику крста у Горском вијениу. Између бројних примјера, посебно су издвојени стихови „Крст засија ка̂ на гори сунце// и сав народ на ноге устаде,// часноме се крсту поклонише“, које у облику сновидовне фантазије изговара сердар Обрад из Мартиновића. У расправи Богољуба Шијаковића разматран је методолошки приступ тумачењу питања христологије у филозофско-религијском спјеву Луча миркокозма, а затим је показано на бројним примјерима из овог истакнутог Његошевог дјела да је лик Христа „путовођа за тумачење неких од најважнијих идеја“ цјелокупног Његошевог дјела (ШијАковић 2010: 43). У расправи Јована Стриковића Кулимуролощко и археииийско у Њеіощевом gјелу из перспективе лакановске психоанализе и на примјеру монолога владике Данила из Горской вијенца сагледана је савремена културолошка актуелност овога дјела. У расправи Саве Дамјанова на примјеру краћих пјесама и спјева Луча микрокозма указано је на значај Његошевог читалачког искуства и богате лектире за разумијевање његове пјесничке поетике. У том смислу Његош је сагледан као „роeta doctus“, који је поред усмене народне традиције, успоставио значајан „рецепцијски дослух“ и интензивна прожимања свога дјела са домаћом и страном класицистичком традицијом. Односи се то на Сарајлију и Мушицког из домаће, а на Гетеа, Милтона, Шилера, Бајрона, Игоа, Ламартина, Вјаземског и Державина, из европске традиције.

2.3. Књижевноисторијске расправе отвара оглед Душана Иванића Дјело

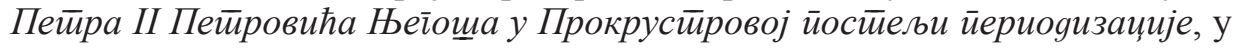
којем је указано на сложене аспекте периодизацијског одређења Његошевог дјела у књижевноисторијским расправама српске књижевности. Усмјера- 
вајући пажњу на истакнуте синтезе Јована Скерлића, Миодрага Поповића, Јована Деретића и Драгише Живковића, указано је на преовлађујуће ставове да Његошево дјело упркос свим опирањима прецизним периодизацијама морамо посматрати на стилско-поетичкој граници између класицизма, предромантизма и романтизма. У расправи академика Наде Милошевић Ђорђевић $О$ неколиким иеесмама у Њеїомевом „Огледалу српском“ анализиране су неке од карактеристичних народних пјесама сакупљених и објављених у Његошевом Оїлеgалу срйском (1845). При томе је посебна пажња усмјерена на оне пјесме које су поред несумњивог народног постанка имале и своје ауторе који су их испјевали по узору на народне стихове. Ради се о пјесмама Бој на Марӣиниће, Похара Жабљака, Поїибија Бећир-беі̆а Бущийлије, Уgар на Салковину. Прва међу њима је према разумијевању сакупљача и тумача народног пјесништва углавном приписивана Петру II Петровићу Његошу, а за остале су изношене различите и непотпуне претпоставке. У детаљној упоредној анализи ових пјесама са бројним другим народним пјесмама посвећеним сродним догађајима, академик Нада Милошевић Ђорђевић закључује да се све четири пјесме о којима је било ријечи у овоме раду „могу сматрати народним песмама“ (Милошевић-ЂорЂевић 2010: 128). У расправи Снежане Самарџије Исиовестии Њеїощевих варалища и фолклорна ірађ, указано је на различите односе између „епике, историје и филозофије“ у Његошевом дјелу, као и прожимања са народном поезијом и европском баштином. Дјелимично је указано и комичне аспекте дјела и пародично-иронијску перспективу у обликовању појединих Његошевих јунака у драмском спјеву Лажни изар Шћейан Мали, као и прозном дјелу Жийије Мрђена Несрейњиковића. У расправи Љиљане Пешикан Љуштановић Помљеgюе вријеме y Горском вијенцу и срйској нарояној йоезији, анализирана је семантичка димензија синтагме „пошљедњег времена“ у Његошевом дјелу у поређењу са њеном употребом у народном пјесништву. У расправи Младена Шукала Оквири срйске къижевне истиорије: Њеїош и Андрић, указано је на Андрићево читање и есејистичко разумијевање Његошевог дјела, са посебним усмјерењем на тематизацију косовског мита. У расправи Владимира Осолника Словеначке новине о Њеїощу (1844-1852), представљено је пет новинских записа у Словенији у којима је у распону од 1844. до 1852. године писано о Његошевом дјелу, Црној Гори и Црногорцима. Представљен је и некролог који је објављен у Новицама 1852. године поводом преране Његошеве смрти. У расправи Јована Делића Њеі̄ощ у вићењу Миоgраїа Павловића, указано је на интересовања овог српског пјесника за Његошево дјело, подједнако из перспективе антологичара, пјесника и есејисте. Посебно је нагла-

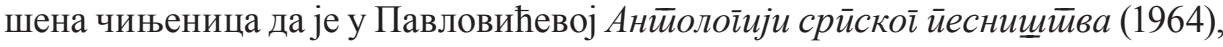
Његош заступљен са четири лирска фрагмента из Луче микрокозма, као и три фрагмента из Горског̆ вијенц̧а. На крају огледа детаљно је анализирана Павловићева пјесма Ловћен, Њеīouy из збирке Хоgogapje (1971), у којој је указано на изразито правилне формалне и сложене значењске аспекте, попут свјетлосне и симболике камена, које се снажно прожимају са Његошевим 
пјесништвом. На основу тога Делић изводи закључак „да је Павловићева пјесма Ловћен, Њеїощу много боља него што је сам Павловић о њој мислио“ (ДЕлић 2010: 209). У огледу Горана Максимовића представљен је Његошев однос и сарадња са Матијом Баном сагледан из четири Банова мемоарска записа о сусретима са Његошем у раздобљу између 1848 . и 1851 . године. Посебно је указано на историјски контекст у којем су се одвијали ти сусрети, на њихов политички значај и на далекосежност посљедица по каснију судбину српског народа. У огледу Весне Вукићевић Јанковић Њейощеви йуйеви ка Лучи микрокозма указано је на кратке пјесме Његошеве, са посебним освртом на пјесму Мисао (1844), као и генезу идеје на којој је утемељен филозофско-религијски спјев Луча микрокозма (1845).

2.4. Историјско језичке расправе о Његошевом дјелу отворене су огледом академика Александра Младеновића Найомена о језику йрвоі изgаға Њеīomевоі Лажног цара Шћепана Малог (1851). Указано је на низ неуједначених језичких особина које се појављују у овом Његошевом драмском спјеву. Младеновић их доводи у везу са постојањем два преписа, од којих је други урађен на Вуковој реформисаној ћирилици на којој је дјело одштампано 1851. године, а на којој није било написано 1847. године. У огледу Мата Пижурице Найомене уз крийичко изяање ЦАНУ Луче микрокозма, Горског вијенца $u$ Лажног цара Шћепана Малог, указано је на специфичне језичке особине и коментаре овога издања Његошевих најважнијих књига које су се појавиле у Подгорици (2004-2007), под уредништвом Бранка Поповића и уз приређивање академика Александра Младеновића и Мирона Флашара.

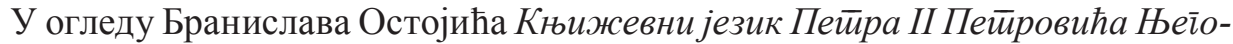
щиа и Вуков модел кьижевной језика указано је на специфичан однос општекњижевног језичког слоја и дијалекатског језичког слоја у најзначајнијим Његошевим дјелима. Направљена су поређења са Сарајлијиним пјесничким језиком, као и са Вуковим дјелима, а посебно преводом Новог завјейа (1847), а затим је изведен закључак да је данашњи модел српског књижевног језика у „битној мјери одређен не само дјелатношћу Вука Караџића већ су му темељи ударени и Његошевим језичким обрасцем који је у пракси непоновљив“ (Остолић 2010: 101). У огледу Драгане Мршевић Радовић Лав, іускка и йет̄аo

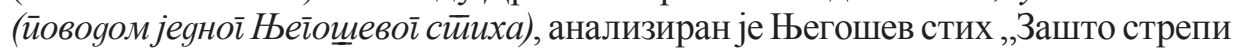
лаф од гуске, кажи?“" као својеврсна значењска загонетка која се и на језичком и на митолошком плану преко симболике „гуске“, у значењу варнице, искре, небеског огња, повезује са митским представама сунчевог рађања и „купања у праводама““ (МРшевић-РАдовић 2010: 103).

3. Други број Њеі̄ощевої зборника Майище срӣске објављен је 2014. године а настао је као Сйоменица поводом обиљежавања двјесто година од рођења Петра II Петровића Његоша. Сачињен је из укупно четрдесет четири огледа у којима су из есејистичке, историографске и књижевноисторијске, из философско-теолошке, из лингвостилистичке, историјско језичке и тексто- 
лошке перспективе, из књижевно-компаративне и преводилачке перспективе, као и културолошке перспективе сагледани различити аспекти Његошевог дјела.

У првој и најобимнијој скупини која обухвата есејистичке, историографске и књижевноисторијске погледе на Његошево дјело, указујемо на радове Мира Вуксановића, Светозара Кољевића, Рајка Петрова Нога, Љубомира Зуковића, Бранка Летића, Зорана Лакића, Душана Иванића, Саве Дамјанова, Радослава Ераковића, Ивана Негришорца, Славка Гордића, Јована Делића, Милутина Мићовића, Ирене Арсић, Бориса Лазића, Предрага Палавестре, Жарка Ђуровића, Љиљане Пешикан Љуштановић и сл. У другој скупини, која је заснована на философско-теолошком приступу Његошевом дјелу, налазе се огледи митрополита Амфилохија Радовића, епископа Јоаникија Мићовића, Димитрија М. Калезића, Богољуба Шијаковића, Милана Радуловића, Милоја М. Ракочевића, Стевана Кордића и сл. У трећој скупини, која је заснована на лингвостилистичкој, историјско језичкој и текстолошкој перспективи, налазе се огледи Слободана Реметића, Милоша Ковачевића, Веселина Матовића, Живка Брковића и сл. У четвртој скупини, која је заснована на компаративном и преводилачком приступу у сагледавању Његошевог дјела, издвајамо огледе Војислава Јелића, Томажа Евертовског, Најде Иванове, Хироши Јамасаки Вукелић, Владимира Осолника, Дејана Ђуричковића и сл. У петој скупини, која је заснована на културолошком приступу Његошевом дјелу, издвајамо огледе Часлава Д. Копривице, Владиславе Гордић Петковић, Драгана Симеуновића, Ненада Макуљевића, Бранке Радовић, Мирољуба Јевтића и сл.

3.1. Међу есејистичким, историографским и књижевноисторијским огледима о Његошевом дјелу указујемо на сљедеће расправе. У огледу академика Светозара Кољевића О Њейомевом наяахнућу 'бесудном земљом' указано је на Његошев пјеснички доживљај Црне Горе као „бесудне земље“. Издвајајући стихове попа Андрије из Лажної цара Шћейана Малої у којима је Његош најнепосредније препознао Црну Гору као „бесудну земљу“, као и бројне друге примјере из Његошевог дјела, преписке и владарских активности, Кољевић наглашава да је та пјесничка синтагма „била темељни уметнички изазов, полазна тачка његовог стваралаштва у којем је он, као и неки његови далеки сродници, Данте и Милтон, изразио своје личне драме, судбину и запажања као оноземаљски доживљај природе људског живота“" (Кољевић 2014: 36). У огледу академика Мира Вуксановића Њейощева gва века мука, на оба свети Његош као владар и пјесник, подједнако за свога живота, као и Његошево дјело и мисао након његовог упокојења. Један од најупечатљивијих примјера Његошевог живота на „оба свијета“ налази се у чињеници да је издање Горскоі вијения на простору Црне Горе урађено тек 1913. године, на стогодишњицу његовог рођења. У огледу академика Рајка Петрова Нога Може

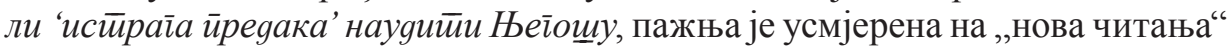


и кривотворења Његошевог дјела, која највише долазе управо из данашње Црне Горе. Иза тога стоји намјера да се кроз такав процес фалсификовања заправо одрекну Његоша и његовог дјела, јер им је он највећа препрека на путу расрбљавања овога простора. У огледу академика Љубомира Зуковића Њеїош и Вук указано је на Вукове везе са Црном Гором још од времена скупљања пренумераната за Срйски рјечник (1818), а затим је анализирана драгоцјена сарадња Вука и Његоша која је датирала од њиховог првог сусрета у Бечу 1833. године, преко штампања књиге Вукових сакупљених народних пословица на Цетињу 1836. године, па све до Његошевог упокојења 1851. године. У огледу академика Бранка Летића „Ноћ скупља вијека“ у конйек-

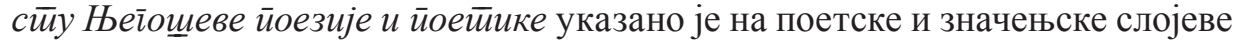
ове једине сачуване Његошеве љубавне пјесме који су најснажније исказани кроз антитезе свијетло и тамно, тијело и дух, чувство и мисао. У огледу Зорана Лакића Њеі̄ощев срйски нароg, Црна Гора и Црноїории из историограф-

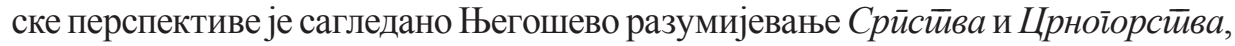
а затим је указано на савремене злоупотребе Његошевог дјела и покушаје поништавања или одрицања од Његошеве идеје Срйстива. У огледу Душана

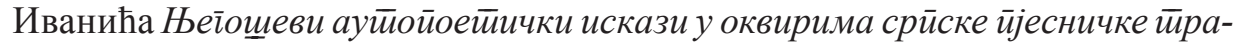
guиије указано је на низ исказа у којима је Његош говорио о природи свога стваралачког поступка, а које је пронашао у стиховима појединих пјесама или спјевова, као и у појединим писмима. На основу свега тога показано је да се Његош „по неким елементима уклапа у ранију пјесничку традицију (Соларић, Мушицки, народна пјесма), а по другима излази из ње“. На основу тога је закључено да је Његошево дјело прошло процес „напуштања класицистичких пјесничких реквизита и постепеног усвајања романтичарско-фолклорног круга“ (ИвАнић 2014: 159). У огледу Љиљане Пешикан Љуштановић Пощљеgње вријеме и косовско ӣреgање коg Сйарца Ращка и у „Горском вијенцу“, направљено је поређење између народног епског виђења, карактеристичног за поједине епске пјесме Вуковог пјевача Старца Рашка, синтагме „пошљедњег времена“, тј. пропасти српских средњовјековних држава, са тематизацијом тог предања у Његошевом Горском вијениу, највише у шест пјесмама кола. У закључку је показано да постоје значајна прожимања у разумијевању тог феномена, поготово на етнографском плану, али да је Његош читаву идеју значајно обогатио поетским, естетским, значењским и идеолошким функцијама. У огледу Радослава Ераковића Лик Сайане у Њеі̄ощевој Лучи микрокозма и релиіијским ейовима срйских йреgроманйичара, указано је на до сада неодовољно проучене тематско-мотивске везе овога дјела са религиозним еповима Константина Маринковића (1784-1844), Викентија Ракића (1750-1818) и Гаврила Ковачевића (1765-1832). Извршеном упоредном анализом дошло се до сазнања о бројним подударностима у обликовању лика Сатане, као и до закључка да су поменути српски предромантичари били „легитимни зачетници поетско-епског жанра, који је у српској књижевности достигао свој врхунац управо са Његошевом Лучом микрокозма“" (ЕРАковић 2014: 235). У огледу Саве Дамјанова Њеі̄ou као ӣрийовеgач, 
филозофско-религијски спјев Луча микрокозма посматран је превасходно као дјело наративне структуре, на основу чега су у њему препозната умјетничка и жанровска својства романтичарског „романа у стиховима“. У огледу

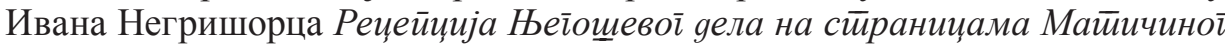
Летописа (1831-1852): прилози Теодора Павловића и Јована Суботића, указано је на снажне везе владике Његоша и његовог дјела са Матицом српском. Указано је најприје на забиљешку из 1831. године у којој је у Лейойису објављена вијест о смрти Петра I Петровића, као и избору младог Рада Петровића за његовог насљедника. Потом је 1834. објављен приказ Теодора Павловића о Његошевој пјесничкој књизи Пустиињак иеетиюски, да би 1837. и 1838. године били објављени и први Његошеви текстови у Летиойису. Наглашено је и то да је Његош 1845. године постао члан Матице српске, да је 1847. године приложио као поклон Библиотеци Матице српске један примјерак Луче микрокозма и пет примјерака Горскої вијенца. Након Његошеве смрти у октобру 1851. године, тадашњи уредник Лейойиса Јован Суботић одржао је у Бечу комеморативну бесједу, а затим је и објавио у Летиойису 1852. године. Посебно је наглашено да је у том Суботићевом тексту „први пут дата заокружена оцена о Његошу владару, владики и песнику, а тиме су постављени основи за развој Његошевог култа у српској књижевности и култури, као и култа Црне Горе као Српске Спарте““(НЕгришорАц 2014: 253). У огледу Бориса Лазића Прилої разумевању развийка иооимања светлосне мисли на йримеру раной Њейощевог йеснищйва (ииклус иеесама из Грлице за 1837. іооину), указано је на значај раних Његошевих рефлексивних пјесама: Вјерни син ноћи ијјева йохвалу мислима и Оgа суниу сйјеватиа у ноћи без мјесеияа, које су претходиле пјесми Мисао (1844) за формирање „светлосне симболике“ у каснијем спјеву Луча микрокозма (1845). У огледу Ирене Арсић Петиар II Пейровић Њеі̄ощ и Ђорђе Николајевић: ува лица срйске gийломайије и државнищйва, указано је на веома сложене односе између владике Његоша и дубровачког „мирског пароха“, каснијег митрополита дабробосанског, Ђорђа Николајевића (1807-1896). У суштини се радило о личностима потпуно различитог темперамента и различитих погледа на дипломатију и државништво, што је у појединим приликама изазивало и озбиљне посљедице по српску православну заједницу у Дубровнику. Упркос томе, а захваљујући прије свега значајној улози Димитрија Милаковића и Матије Бана, Његош и Николајевић су остварили обострано корисну и значајну сарадњу. У огледу Славка Гордића „Његошеви трагови у српском песништву двадесетог века“ указано је на значај који је Његошева пјесничка поетика остварила на креацију појединих савремених српских пјесника, а прије свега Васка Попе, Бранка Миљковића, Стевана Раичковића, Миодрага Павловића, Ивана В. Лалића, све до Љубомира Симовића, Матије Бећковића, Слободана Ракитића, Момира Војводића и др. У огледу Јована Делића Майија Бећковић и Њеїом указано је на снажне поетичке везе Бећковићевог са Његошевим пјесништвом. Показано је то кроз анализу појединих Бећковићевих есеја и бесједа, као и седам Бећковићевих пјесама о Његошу. При томе је указано и на запажено 
истраживање Стевана Кордића који је одбранио докторску дисертацију Ње$\bar{\imath} о \underline{u}$ и Мат̈ија кроз сагледавање дјела ове двојице писаца као „два супротна, али међусобно комплементарна опуса о истиом и да та два опуса заједнички граде јеgно иело“" (ДЕлић 2014: 297).

3.2. Међу философско-теолошким расправа посвећеним Његошевом дјелу указујемо на сљедеће запажене текстове. У огледу преосвећеног ми-

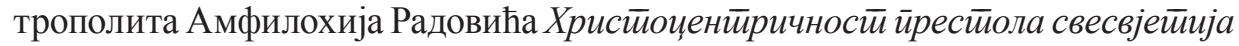
üo Њет̄oщy анализирани су наглашени христоцентрични аспекти Његошевог дјела, а кроз анализу Његошевог поимања појмова „Слово“, „Ријеч“ и „Логос“, указано је на „истовјетност са Логосом Јовановог јеванђеља“ (РАдовић 2014: 11). Тиме је потврђена основна аналитичка теза за теолошко читање Његошевог дјела по којој „Слово“ представља стожер свеукупне пјесникове мисли, „његовог тајновиђења, његовог опита“, а као такво представља његово „пророчко виђење и његов увид у тајну Божију, у тајну престола Вишњег, у тајну свих свјетова, у тајну Божијег свесвјетија““(РАдовић 2014: 17). Важно је нагласити и то да је наведена расправа преосвећеног митрополита Амфилохија изговорена као бесједа 16. фебруара 2013. године на свечаној сједници Матице српске поводом њеног 187. рођендана, којом је обиљежен почетак прославе двјесто годишњице Његошевог рођења. У огледу преосвећеног епископа Јоаникија Мићовића Царска йорфира указано је на аутентичност Његошевог мистичног доживљаја свијета, тако да његова мистика и поетика не трпе површна и непотпуна појашњења и појмове. Усмјерене су на преношење доживљаја и духовних открића и као такве „служе се најдубљом символиком и терминима апофатичког богословља“. На крају расправе епископ Јоаникије закључује да „светодуховска знаковитост таинствене порфире, најмистичнијег Његошевог символа Божије царствености, има основу у иконографији и у писаном предању источноправославне духовности“"(Мићовић 2014: 19). Указујемо и на оглед Димитрија Калезића Пийање хейероgоксије коg Њет̆оща у којем је посебна аналитичка пажња усмјерена на мање истицани феномен „стварања свијета“ у спјеву Луча микрокозма, који је остао у сјенци бројних тумачења феномена преегзистенције у овом дјелу. У огледу

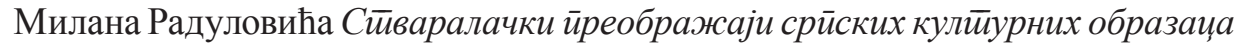
y Њеїощевом йјеснищйву, кроз креативни аналитички спој културолошког и теолошког приступа Његошевом дјелу, указано је на чињеницу да се његова „поезија показује као велика културна синтеза класичних културних образаца и као духовна вертикала српске историје и народне егзистенције“ (РАдуловић 2014: 147).

3.3. Међу лингвостилистичким, историјско језичким и текстолошким огледима, указујемо на сљедеће расправе. У огледу академика Слободана

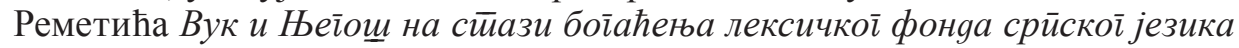
показан је допринос Вука Караџића и Његоша „богаћењу лексичког потенцијала српског књижевног језика“"(РЕметић 2014: 79). То се посебно односило на недовољност лексичког фонда народног језика приликом изражавања 
апстрактних категорија неопходних за поезију, теологију и философију. У исцрпној анализи је показано да су и Вук и Његош тај проблем рјешавали на два плана: кроз адаптацију ријечи из словенских и других језика, као и кроз успјешно стварање кованица у духу српског језика. У огледу Милоша Ковачевића Њеїощев оунос йрема срйском језику размотрени су непосредни и посредни Његошеви ставови према српском језику. Најчешће су поетски обликовани у форми имплицитних или експлицитних исказа у лирским пјесмама или у филозофско-религијским и драмским спјевовима. При томе је посебна пажња усмјерена на оне језичке критеријуме које је Вук Караџић поставио у темеље стандардног српског језика. На основу тога је у закључку констатовано да је Његош „готово безрезервно био на путу Вукових рјешења о српском књижевном језику““ (КовАчевић 2014: 169). У огледу Веселина Матовића Њеїощ у ирноїорским уибеницима за језик и књижевносии указано је на беспризорне облике фалсификовања и злоупотреба Његошевог дјела у новоцрногорским уџбеницима језика и књижевности са циљем негирања српског језика и српског идентитета на простору данашње црногорске државе. Захваљујући томе Његошево дјело је постало предмет политичких манипулација и „менталног инжењеринга“ тамо гдје је то „најмање допустиво - у школским уџбеницима“ (МАтовић 2014: 529). У огледу Живка Брковића Cygбина рукойиса Горског вијенца указано је на важне текстолошке аспекте овог најбољег Његошевог дјела, а затим је покушано одгонетнути шта се десило са његовим рукописом. Прије свега се то односи на проналажења одговора на два питања: „Чији је I део рукописа Горскої вијенца?“ и „Где је II део рукописа Горскої вијенца?“.

3.4. У оквиру компаративних читања Његошевог дјела указујемо на сљедеће расправе. У огледу Војислава Јелића Њеīou и poeta doctus указано је на реторичке и поетичке везе Његошевог дјела са антиком, а на основу Његошевог разумијевања појма „период“ указано је на његово разумијевање улоге учитеља, школе, књиге и образовања. У огледу Томажа Евертовског Два йойлеgа на Вечни іррая - доживљај Рима у сииваралащйву Њеїоща и Миикјевича, кроз анализу једног доминантног пјесничког мотива, какав је био доживљај града Рима, указано је на блискости и разлике двојице пјесника, Његоша и Адама Мицкјевича. Предмет анализе су била писма, записи и књижевна дјела српског и пољског књижевника, као и свједочанства њихових савременика, у овом случају и сапутника, путописаца Љ. Ненадовића и А. Одињца. У огледу Најде Иванове Проблем ияенииификаиије реиейиивних

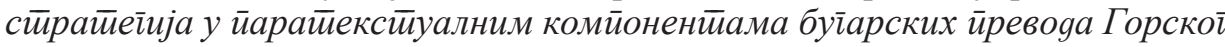
вијенца, указано је на два превода овога дјела на бугарски језик, са посебним освртом на социокултурни контекст, који је значајно условио природу коментара и превода појединих стихова. У огледу Хироши Јамасаки Вукелић O йревођеюьу Горског вијенца $и$ Луче микрокозма на јайански, указано је на специфичности превода овога дјела на језик народа који припада потпуно другој култури и другој породици језика, али који је захваљујући изразитом 
труду и знању преводиоца Казуо Танаке, урађен на успјешан начин. У огледу

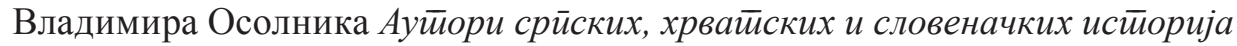
книжевностии о Њеі̆ощевом Горском вијенцу, указано је на облике рецепције овог најбољег Његошевог дјела у књижевноисторијским синтезама поменутих јужнословенских народа. У српској књижевности та истраживања су ишла све до Јована Суботића и Јована Ристића, из средине 19. вијека, а затим су преко Стојана Новаковића, Андре Гавриловића, Павла Поповића и Јована Скерлића, обухватила историје српске књижевности све до краја 20. вијека и истакнутих синтеза Миодрага Поповића и Јована Деретића. У хрватској књижевној историографији сагледани су помени Његошевог дјела од друге половине 19. вијека и студија Ивана Филиповића и Ђуре Шурмина, па све до књиге Мате Ујевића из 1932. године у којој је први пут хрватска књижевност посматрана одвојено од српске књижевности, па самим тим није обухватила поглед на Његоша као писца. Указано је и на кратку историју књижевности Словенаца, Хрвата и Срба словеначких аутора Ивана Прегеља и Францета Томшича, из 1938. године, у којој је Горски вијенаи сагледан као „највише и најљепше“ дјело у српској књижевности (Осолник 2014: 486).

3.5. Међу културолошким студијама појављују се разнолика истраживања Његошевог дјела, као што је сагледавање политичких аспеката, у огледу Драгана Симеуновића, Његошевог доживљаја ислама и односа према конвертитству, у огледу Мирољуба Јевтића, као и значај Његошевог дјела за разумијевање и чување савременог српског идентитета, у огледу Часлава Д. Копривице.

Овом приликом посебно указујемо на текстове Бранке Радовић и Ненада Макуљевића. У огледу Ненада Макуљевића Савременик, херој и светиийељ: креирање Њеі̄ощевог лика у визуелној кулйури указано је на бројне и разноврсне сликарске портрете, дагеротипије и литографије Петра II Петровића Његоша. Издвојене су двије врсте Његошевих портрета: архијерејски и народни портрети. Најранији по времену настанка је Његошев архијерејски портрет из 1833. године који је урадио руски сликар Моргунов одмах након његовог рукоположења за епископа у храму Преображења Господњег у Петрограду. Други архијерејски портрет настао је у Трсту 1837. године а урадио га је словеначки сликар Јожеф Томинц. Најизразитији иконички портрет Његошев настао је у Темишвару, али „нису познати извори који би указивали на тачно време настанка, сликара и порекло овог портрета, што отежава разумевање његове првобитне функције“ (МАкуљЕвић 2014: 513). Ликовна представа Његоша као народног владара такође је дала изузетне портрете. Посебно је издвојен изузетни рад Анастаса Јовановића, који је био први српски фотограф и литограф, а који је 1847. године у Бечу литографисао Његоша у народном одијелу. Исте године сличну Његошеву литографију у народном одијелу урадио је и бечки сликар Аугуст Принцхофер. У другом дијелу огледа указано је и на значајне споменике посвећене Његошу, који су 
настајали након његове смрти, од друге половине 19. вијека, па све до наших дана. Прву идеју о подизању Његошевог „коњаничког споменика“ урадио је Анастас Боцарић у Задру 1899. године. Први јавни споменик посвећен Његошу подигао је Јован Дучић у Требињу 1934. године, а израдио га је Тома Росандић. Указано је и на значајне Његошеве скулптуре које је урадио Сретен Стојановић, најприје у Подгорици 1954. године, а након тога је на основу истог предлошка урађена и скулптура која је 1994. године постављена на плато испред Филозофског факултета у Београду. Његошева скулптура урађена по нацрту Сретена Стојановића постављена је 2013. године у и Андрићграду у Вишеграду. У огледу је указано и на израде Његошевих медаља и плакета, као и на све оне непријатне околности које су пратиле рушење Његошеве капеле на Цетињу и подизању маузолеја на основу пројекта Ивана Мештровића, у сарадњи са архитектом Харолдом Билинићем, 28. јула 1973. године.

У огледу Бранке Радовић Нове комйозичије срйских и ирноїорских ауйоpa Њеі̄oщy указано је на музичке композиције и музичке интерпретације Његошевих пјесама. У истраживању које је иначе било дио докторске дисертације Бранке Радовић, објављене једним дијелом у књизи Њеіом и музика (2001), пронађено је, пописано и регистровано, а затим анализирано 50 пјесама написаних на Његошеве стихове и прозу од прве половине 19. вијека, док је Његош био жив, па све до 2014. године. Најстарија позната композиција је Огњановићева Посвейа йраху оиа Србије, издвојена је и музика Исидора Бајића из 1901. године која је била намијењена за представу Горскої вијенциа у Новом Саду, а међу најпознатијим из новијег времена су композиције које су радили Дејан Деспић и Жарко Мирковић, све до најновијих композициja Александра Перуновића, Нине Перовић, као и Татјане Прелевић и Марка Рогошића. У закључку је указано и на значајне умјетничке домете и жанровску разноврсност композиција посвећених Његошевом дјелу, али је исказан и критички став према наглашеној незаинтересованости државе за обиљежавање Његошевог јубилеја двјесто година од рођења, 2013. године.

3.6. На крају броја уврштена је преписка, коју су Матица српска и Његошев одбор Матице српске, упућивали различитим државним огранима Републике Србије и Републике Српске, као и институцијама САНУ, АНУРС, ЦАНУ, Синоду Српске православне цркве и другима, у настојању да се на адекватан начин обиљежи јубилеј Двестио іояина Њеїощевоі рођења. Одмах иза тога, као посебан документ, објављен је и Извещйај Майице срйске по-

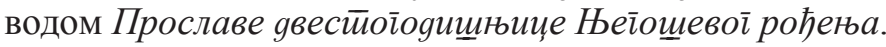

4. Трећи број Њеі̄ощевог̄ зборника Майице срйске, који је објављен 2018. године, окупио је и штампао саопштења која су изговорена на научном скупу Къиіе о Њеīomy, одржаном у Новом Саду, 13. новембра 2017. године у организацији Његошевог одбора Матице српске. Основни циљ наведеног научног скупа састојао се у томе да поновно афирмише неке од најрепрезентативнијих 
монографских студија и расправа које су битно допринијеле разумијевању и тумачењу Његошевог дјела и личности у распону дужем од стотину година: од појаве књиге Павла Поповића О Горском вијенцу $\left(1900^{1}, 1923^{2}\right)$, расправе Бранислава Петронијевића Филозофија у Горском вијениу (1908), те књиге Николаја Велимировића Релиїија Њеїощева (1911), па све до три књиге Мила Ломпара: Њеі̄ощи и модерна (1998), О йраїичком иеснику (2010) и Њеїощево иеснищитво (2010).

4.1. У уводном дијелу зборника објављена су поздравна обраћања преосвећеног владике Иринеја Буловића и председника Матице српске Драгана Станића, у којима је указано на неодвојивост српске културе и Његошеве личности и дјела. Преосвећени епископ Буловић осврнуо се на посебну драгоцјеност овога скупа зато што се као теме истраживања појављују „најтрајније књиге писане о Његошу“, које су створили „они најбољи и најдубљи“, попут светог владике Николаја Велимировића, Ива Андрића, Исидоре Секулић и Анице Савић Ребац (Буловић 2018: 9). У излагању Драгана Станића посебно је наглашена Његошева веза са Матицом српском и улога Матице у афирмисању и критичком вредновању Његошевог дјела. При томе је указано на чињеницу да је уредник Летиойиса Теодор Павловић написао први критички текст о Његошу поводом објављивања његовог пјесничког првенца Пустиињак иетииғскки (1834) и штампао га у 39 броју Летиойиса крајем 1834. године. „Теодор Павловић је представљао најчвршћу спону Његоша и Матице српске“"(СтАнић 2018: 12), што се најбоље види у чињеници да је Његош постао сарадник у Лейойису 1837. године када је објавио оду „Нелажниј знак памети праху народољупца“ поводом смрти Лукијана Мушицког (1777-1837), а касније је 1845. године постао члан Матице српске. Станић је указао и на чињеницу да је након Његошеве смрти 1851. године, Матица достојно ожалила рано преминулог пјесника, а посебно је издвојен некролог Јована Суботића који је као уредник објавио у Летиойису 1852. године.

Уводник академика Мира Вуксановића, уредника Њеїощевог зборника Майище срйске, под насловом С Њеїощем боље знамо ко смо, представља осврт на више актуелних питања које отвара Његошево дјело у нашем времену. Најприје на чињеницу да скуп означава јубилеј 170 година од објављивања Горской вијенциа, као и подсјећање на „велики значај 1847. за српску духовност, језик, књижевност и културу““ (Вуксановић 2018: 17). Затим на чињеницу да је од Његошевог упокојења 1851. године написано и објављено више од четири стотине посебних издања о дјелу овог великог ствараоца, рачунајући при томе и рјечнике, монографске публикације и бројне књиге, често штампане у више издања. Поред свега тога, Вуксановић указује и на чињеницу да Његош ,,још није изучен како заслужује“, те да је „кривотворен како не заслужује“, да је клеветан, извртан и изокретан, да му је поништаван српски идентитет, нарочито у посљедњих неколико година (ВуксАновић 2018: 17). Наведени научни скуп и овај трећи број Њет̆ощевоі зборника Майище срйске представља и велико признање свима онима који су писали 
о Његошевом дјелу, чије књиге представљају важне датуме у историји српске књижевности, те којима су постављени темељи „његошологије“. Међу тим ауторима посебно су издвојена имена: Ива Андрића, Павла Поповића, Милосава Бабовића, Николаја Велимировића, Алојза Шмауса, Миодрага Поповића, Јована Деретића, Милована Ђиласа, Мишела Обена, Бранислава Петронијевића, Анице Савић Ребац, Исидоре Секулић, Мирона Флашара, Слободана Томовића, Мила Ломпара и многих других. Упркос томе, Вуксановић наглашава да је још увијек ,пред нама широко Његошево поље“ (ВукСАновић 2018: 18), да је то већ показао десетогодишњи истраживачки рад Његошевог одбора Матице српске, а да ће у наредним деценијама тек доћи до изражаја и бити сасвим видљиви сви постављени и урађени послови.

У надахнутој „,апотеози“ Матије Бећковића, насловљеној Светии Пейар

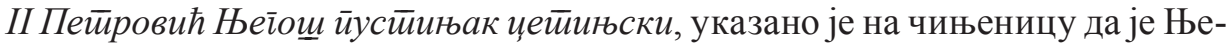
гошев светитељски култ у српском народу несумњив, иако га црква није званично прогласила за светитеља. При томе се Бећковић посебно позива на Николаја Велимировића и његову гласовиту расправу Релиіија Њеі̄ощиева (1911) у којој је изнијета тврдња да у српској историји нема личности која би се могла у погледу своје религиозности мјерити са Његошем, наглашавајући да је то био истински „Великомученик“. У даљим запажањима, Бећковић се осврће на бројне кратке пјесме Његошеве, посебно издвајајући пјесму „Црногорац к свемогућем Богу“, те магистрални филозофско-религијски спјев Луча микрокозма. Све то, уз многе друге појединости, по Бећковићевом мишљењу препоручује Његоша да га „прибројимо у Сабор светих“, чему би се обрадовали сви српски светитељи од Светог Саве и Светог Петра Цетињског, Светог Василија Острошког, до Светог Николаја Лелићког и Светог Јустина Ћелијског, те Светог Вукашина Клепачког (БЕћковић 2018: 27).

4.2. Средишњи дио броја испуњава шеснаест „саопштења“ чији су аутори: Јован Делић, Радомир В. Ивановић, Микоња Кнежевић, Радојка Вукчевић, Горан М. Максимовић, Лидија Томић, Душко Н. Бабић, Борис Лазић, Илија Марић, Душко В. Певуља, Ненад Николић, Мило Ломпар, Иван Негришорац, Драго Перовић, Војислав П. Јелић и Љиљана Ж. Пешикан-љуштановић. На крају броја објављена је „библиографија“ Слађане Субашић

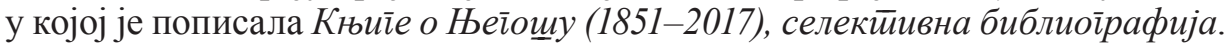
Сасвим на крају зборника објављен је као „прилог“у фототипском облику „Програм научног скупа Kњйе о Њеīouy“".

Наглашавамо да су тумачења изабраних „књига о Његошу“ заснована на три групе радова. Прву групу чине текстови у којима су интерпретирани есејистички погледи српских писаца на Његошево дјело (Иво Андрић, Исидора Секулић, Милован Ђилас), другу групу текстови засновани на књижевноисторијским интерпретацијама Његошевог дјела (Павле Поповић, Миодраг Поповић, Јован Деретић, Милосав Бабовић, Мило Ломпар), трећу групу текстова чине расправе утемељене на страној рецепцији и тумачењу компаративних студија о Његошевом дјелу (Алојз Шмаус, Мишел Обен, 
Едвард Денис Гој, Мирон Флашар), а четврту групу текстови у којима су сагледане филозофско-теолошке расправе о Његошевом дјелу (Николај Велимировић, Бранислав Петронијевић, Аница Савић Ребац, Слободан Томовић).

4.3. Међу есејистичким текстовима о Његошу средишње мјесто заузима десет Андрићевих расправа. Посебно издвајамо два огледа: Њеі̄ом као йраіични јунак косовске мисли и Вечна иирисуйносй Њеїощева. Оглед Јована Делића, који је до сада написао пет огледа о односу Андрића према Његошу, а који овом шестом приликом носи наслов Иво Анgрић о Њеїощy, представља „малу поетичку синтезу“свих десет Андрићевих есеја из којих се очитава висока мјера поштовања и оданости јединог нашег нобеловца према Његошевом дјелу и личности. У огледу Ивана Негришорца размотрене су књижевнотеоријске идеје које су уграђене у познату есејистичку студију Исидоре Секулић Њеі̄ощу књиі̆а яубоке о аностии (1951). При томе су као посебно значајне издвојене мистично-религијске идеје о пјесниковој „свјетлосној природи“ (исихазам, таворска свјетлост), а затим и „теорија генија“ и „теорија хероја“, као и „теорија уживљавања и интуиције“. У Исидориној књизи о Његошу долазе до изражаја и добри митско-архетипски и културолошки увиди: од Вука Караџића и његовог разумијевања српске културе, преко Дучићевих митскопјесничких слика, па све до Нортропа Фраја са којим је дијелила увјерења о блискости књижевности и мита. У огледу Лидије Томић анализиране су двије књиге Милована Ђиласа: Леїенgа о Њеі̄ощy (1952) и Њеїощи: йјесник, влаgар, влаgика (1988). При томе је указано на чињеницу да је Ђиласова анализа најважнија три Његошева спјева: Луче микрокозма (1845), Горскої вијениа (1847), Лажної цара Шћейана Малої (1851); резултат изврсне контемплације, али и веома промишљених историјских, друштвених и поетских сазнања.

4.4. У другој скупини огледа, који су обухватили књижевноисторијске интерпретације Његошевог дјела, академик Радомир В. Ивановић је анализирао допринос Милисава Бабовића развоју његошологије на примјеру двије његове књиге Њеі̄ощи и сљеgбеници (1993) и Поейика Горской вијенца (1997). Ненад Николић је анализирао студију Павла Поповића О Горском вијениу $\left(1900^{1}, 1923^{2}\right)$, при чему је указао на чињеницу да је занемаривање метафизичке димензије овог Његошевог дјела довело до „раслојавања монографије“" и постојање наглашене неусаглашености појединих поглавља, као и одсуства адекватног закључка. Душко Певуља је анализирао књигу Миодрага Поповића Боник иетииґски (1984), при чему је указао на чињеницу да је анализа три различита облика поетског исказа (љубавног, космичког и херојског), била утемељена на добром познавању биографских и историјских чинилаца, генезе умјетничког сазријевања, те естетичко-филозофских претпоставки Његошевог дјела. Горан Максимовић је анализирао студију Јована Деретића Комйозиција Горской вијенца (1969), при чему је указано на особености Деретићевог књижевноисторијског метода у којем долази до креативне синтезе контекстуалног и текстуалног приступа. Уочљиво је то 
у самом дефинисању појма композиције, преко истраживања генезе дјела и повезаности са другим текстовима, прије свега са Лучом микрокозма, до тумачења структуралних чинилаца (однос дијелова и цјелине, прозна саопштења аутора, дијалози, монолози, систем ликова и сл.), као и жанровске типологије дјела. У закључку је указано на потпуну оправданост главне Деретићеве истраживачке тезе да се умјетничка природа Горской вијенца не може тумачити „нормама традиционалне поетике“, већ на основу критеријума и норми изведених из оригиналне његошевске поетике и самог магистралног текста дјела. Душко Бабић је анализирао књигу Мила Ломпара Њеїощево $\bar{u} е с н и \underline{u} в о$ (2010), при чему је нагласио да је овом књигом Ломпар заокружио своје вишедеценијско бављење Његошевим дјелом, што се види у прет-

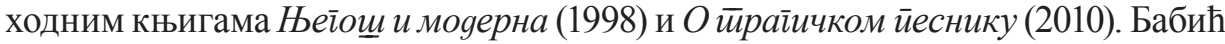
наглашава да је у књизи Њеі̆ощево йеснищйво Ломпар обухватио скоро цјелокупан пјесников опус, а ослањајући се на идеју Лајбницове монадологије (на коју су претходно указали Драган Недељковић и Јован Деретић), као сржне одреднице за разумијевање Његошевог односа човјека и космоса, изградио је свој „методолошки пандан“ “оји му је омогућио да прати „унутрашњи саморазвој Његошевог дела“" (БАБић 2018: 113).

4.5. Трећу скупину чине текстови посвећени страној рецепцији и интерпретацији компаративних студија о Његошевом дјелу. Љиљана Пешикан Љуштановић представила је студије њемачког слависте Алојза Шмауса посвећене Његошевом дјелу, а писане у дужем раздобљу (1927-1964) и на крају обједињене у књизи Cйyguje o Њеĭowy (2000). Ради се о студијама које су два најзначајнија Његошева спјева Лучу микрокозма и Горски вијенац вишеструко контекстуализовале у националној, али и европској и свјетској књижевности (Данте, Милтон и сл.). Борис Лазић у огледу посвећеном француском слависти Мишелу Обену, који је своја истраживања о Његошу на крају објединио у књизи Њеїош и истиорија у иесниковом gелу (1989), указује на добре политичко-историјске, књижевноисторијске и компаративне увиде, који су овог аутора сврстали у ред најбољих тумача Његошевог дјела. Радојка Вукчевић је анализирала књигу Сабља и ӥјесна (1995) британског слависте Едварда Дениса Гоја, која је српској јавности представљена заслугом академика Светозара Кољевића. У анализираној књизи посебна пажња била је усмјерена на читање Горског̄ вијенца, али и кратких пјесама и других Његошевих текстова, у кључу англосаксонске „нове критике“. Вукчевићева након пажљиве анализе закључује да је британски слависта имао добар увид у српску рецепцију Његошевог дјела (П. Поповић, И. Секулић, М. Ђилас, М. Поповић, Ј. Деретић), да је препознао у Горском вијениу умјетничку снагу која Његоша чини великим пјесником, те да је то довољан разлог да Сабљу и йјесну оцијенимо као изузетан дипринос освјетљавању његошевске поетике из једног посебног читалачког угла. Војислав Јелић се позабавио интерепретацијом познате компаративне студије Мирона Флашара Њеі̄ощ и анйика (1997), при чему је посебно издвојио „мотив природе која се снабдева 
оружјем“(Јелиъ 2018: 273), што је Флашар довео у везу са бројним античким узорима, а посебно Анакреонтом и Цицероном.

4.6. Четврту скупину чине текстови посвећени интерпретацији филозофско-теолошких расправа о Његошевом дјелу. Илија Марић анализирао је познату студију Бранислава Петронијевића Филозофија у Горском вијениу (1908), при чему је указао на суштинска питања која су важна за разумијевање Његошеве философије, како на пјеснички начин одговорити на филозофске идеје о постојању Бога, бесмртности душе, философији природе, песимизму и сл. Микоња Кнежевић је анализирао расправу Николаја Велимировића Релиі̄ија Њеі̄ощева (1911), при чему је указао на изразиту субјективност и посебности теолошке херменеутике, те превасходни циљ Велимировића да понуди „слику душе Његошеве“ и да „оваплоти Његошеву душу у себи“" (Кнежевић 2018: 61). Анализирајући однос између историје идеја и тумачења Његошевог дјела, Мило Ломпар је представио расправе Анице Савић Ребац о Његошу. Посебно оне које су посвећене генези спјева Луча микрокозма, као и односу мистицизма и еротског у пјесми Ноћ скуйља вијека. При томе је Ломпар указао на „предности њеног разумевања Његошевих песничких слика у односу на друга тумачења песниковог дела“, али и на одређена ограничења која су била ,условљена њеном методологијом и аутентичном духовном позицијом“ (ЛомпАР 2018: 181). Посебно су упоређени односи између гностицизма и хришћанства, као и укрштање структурално-типолошког са хронолошко-историјским методом, али је указано и на недостатке тог тумачења због „занемаривања присуства елемената спекулативне мистике“, као и неуказивање „на присуство култско-афективне мистике“ (ЛомпАР 2018: 189-190). У огледу Драга Перовића урађена је анализа расправа Слободана Томовића посвећених Његошевој Лучи микрокозма. При томе је посебно издвојена књига Њеїощева Луча (1971), као и њој комплементарна књига Њеі̄ощева филозофија йрироgе (1975), у којима је на продубљен начин сагледана панкосмичка етичка философија пјесникова. Перовић наглашава да је Томовић настојао да Његошево дјело „разумије у пречишћеној философској потенцији“, због чега је остављао у другом плану оно што је „Пренесено као библијско и црквено учење и искуство“ (ПЕРовић 2018: 271), те да је тек у каснијем дјелу Хрисйос - моја истиина, Томовић сагледао настанак Луче микрокозма као Његошево „озарење Божијом енергијом“.

4.7. Поглед на селективну библиографију књига о Његошу (1851-2017), коју је сачинила Слађана Субашић, упућује нас на бројне важне књиге, студије и расправе написане о Његошевом дјелу. Многе од њих су анализиране, а неке су само поменуте у огледима који су уврштени у представљени трећи број Њеі̄ощевог̄ зборника Майице срйске, што нам само казује да је рецепција Његошевог дјела велика и жива дјелатност која нам отвара врата за организацију бројних нових научних скупова и издања посвећених овом аспекту истраживања Његошевог дјела. Само укратко помињемо неке од истраживача чије би књиге могле да завриједе поновна читања и тумачења 
(Павел Аполонович Ровински, Милан Решетар, Љубомир Стојановић, Лазар Томановић, Лазо М. Костић, Димитрије Л. Машановић, Жарко Видовић, Живко Ђурковић, Димитрије Калезић, Амфилохије Радовић, Јован Стриковић и др.). Вриједило би у перспективи усмјерити пажњу и на текстолошки приступ и сагледати најважнија међу бројним издањима и коментарима Његошевих дјела. Утолико прије што је у новије вријеме Његошево дјело, како смо више пута нагласили, изложено бројним клеветама, злоупотребама и учитавањима, као и фалсификованим издањима која долазе из екстремистичких бошњачких кругова или из редова острашћених милогорских креатора политичког инжењеринга заснованог на промјени националне свијести српског народа на простору Црне Горе, Старе Херцеговине и Боке Которске.

5. Четврти број Њеїощевої зборника Майице срйске изашао је 2020. године, а окупио је поред уводне ријечи академика Мира Вуксановића Њеіомев gан Матиице срйске, те два уводна текста академика Мира Вукасновића и академика Михаила Стевановића, укупно осам радова који су изложени као саопштења на научном скупу Језик у Њеїощевим делима, који је одржан у Матици српској, 14. новембра 2019. године. У основи се ради о расправама које су из четири перспективе сагледале језик Његошевог дјела: лексикографске, историјско језичке, дијалекатско-морфосинтаксичке и текстолошке. У прву скупину улази расправа академика Мира Вуксановића „Треба нам свака Његошева реч (За ново издање Речника Њейощева језика)“, као и изнова прештампани предговор академика Михаила Стевановића за издање двотомног Речника Њеіомева језика из 1983. године Сврха и начин израgе овоїа gела. Другу скупину чине огледи Јасмине Грковић-Мејџор, Александра Милановића, Исидоре Бјелаковић, Ане Пејановић и Мата Пижурице. Трећу скупину чине огледи Јелице Стојановић и Миодрага В. Јовановића. Четврту цјелину представља расправа Радмила Маројевића Текстиолощки

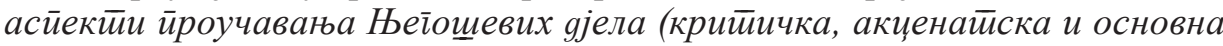
изgаға). Као прилози на крају четвртог броја објављени су осврт Горана Максимовића посвећен издању трећег броја Њеі̄ощевог зборника Майице срйске „Пред репрезентативним књигама написаним о Његошевом дјелу“, као и програм научног скупа Језик у Њеїомевим gелима.

5.1. У уводној ријечи академика Мира Вуксановића наглашено је да се у двовјековном раду Матице српске главна пажња усмјерава на истраживање српског језика и књижевности, „без одвајања да ли је то било у предвуковском добу или по Вуковом мерилу“, а са основном намјером да „изучава развој, континуитет и природну целовитост српске културе, науке, просвећености и уметности, да мири традицију и савремено, указујући где је суштина националног и цивилизацијског, историјског и верског, духовног и митског, да доследно подсећа на Србе који су обележили епохе и стваралачке сусрете са другим народима“"(ВуксАновић 2020: 7). У том контексту је сасвим 
логично оснивање Њеі̄ощевої оgбора Майице срйске, а није случајно да се то десило исте оне године „када се Црна Гора издвојила из државне заједнице са Србијом“ и када се тако „почела одвајати и од Његоша“ (ВуксАновић 2020: 7). Имајући у виду чврсте Његошеве везе са Матицом српском још од 1834. године, када је у Летиойису објављен приказ Теодора Павловића о Његошевој збирци Пусиииљак иеетиюьски, а затим на каснији однос Матице српске према Његошевом књижевном дјелу након пјесниковог упокојења 1851. године, Вуксановић наглашава да „нема сигурнијег места за Његошев стих, реч и мисао“ него што је Матица српска (ВуксАновић 2020: 7). У уводној ријечи је наглашено и то да је од 2019. године по први пут 14. новембра, на дан Његошевог рођења, приређен и „Његошев дан“ у Матици српској. Указано је и на усвојени предлог да Матица српска буде издавач другог, допуњеног и редигованог издања Речника Њеі̄ощевог̄ језика из 1983. године, који је сачинио академик Михаило Стевановић (1903-1991). То је и главни разлог зашто је као један од два уводна текста у четвртом броју Њеїощевог зборника Мa$\bar{u}$ ие срйске објављен Стевановићев предговор за прво издање поменутог рјечника.

5.2. У уводном тексту академика Мира Вуксановића Треба нам свака Њеі̄oщева ријеч управо је указано на значај рјечника, као најбољих и најпотребнијих књига за укупно „памћење народа и његових векова“ (ВуксАновић 2020а: 11). У том контексту је указано на значај урађеног и објављеног Рјечника Њеі̄ощевоі̄ језика академика Михаила Стевановића, као што је указано и на потребу израде рјечника, као и критичких издања или поновних издања дјела истакнутих српских писаца. У помињаном и овдје прештампаном предговору академика Михаила Стевановића Сврха и начин израgе ової gела, указано је на историју српске лексикографије, од Вуковог Срйской рјечника $\left(1818^{1}, 1852^{2}\right)$, преко Даничићевих лексикографских подухвата у

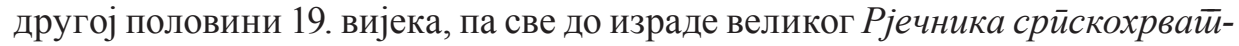
скої нарояноі̄ и књижевної језика у реализацији Института за српскохрватски језик САНУ у другој половини 20. вијека. Стевановић је истакао огромно лексичко богатство језика Његошевог дјела, са напоменом да тај језик „није био само народни него богатији од народног“, те да је као такав ушао у „основе српског књижевног језика“" (СтевАновић 2020: 17).

5.3. У историјско језичким огледима издвајамо расправу академика Јасмине Грковић Мејџор Језик обичајног̄ йрава у Њеїощевим gелима у којој је издвојила и анализарала терминологију и ,формуличне исказе“ обичајнога права у Његошевим дјелима. Издвајамо сљедеће примјере: вјера, дати, чинити, ухватити, држати, разрушити, сломити, разбити вјеру, мир, свето, вражда, суд, дуг, наказа, наказати, умир. При томе је показано да се у већини случајева ради о терминима и формулама наслијеђеним из старосрпског и праславенског обичајног права, са ријетким „дијалекатским иновацијама“. У закључку истраживања је наглашено да се сагледавање овог „лексичкој слоја у дијахроној и општесловенској перспективи“, показало као неопходан 
пут у „дефинисању лексичких (српских, црквенословенских, руских) и семантичких (предхришћанских, хришћанских) слојева у Његошевим делима“ (Грковић-Мејџор 2020: 45). У огледу Александра Милановића Њеїощи и славеносрйска йраqииија указано је на улогу славеносрбизама (лексичких хибрида), неологизама (кованица) и славенизама у Његошевом дјелу, у садејству са лексиком народних говора. Указано је и на значај Његошевог језика за разумијевање односа књижевнојезичког и културног центра и периферије, као и „утицај Његошевог језичког израза на друге писце доситејевске славеносрпске епохе“ (МилАновит 2020: 91). Сродан феномен само на корпусу Његошеве преписке истражен је у огледу Исидоре Бјелаковић, Елеменйи славеносрйской у језику Њеїощевих йисама. Ради се о писмима која су настала између 1830. и 1841. године (а тумачена су према издању Душана Вуксана из 1940. године), а у којима је из социолингвистичке перспективе посебно анализирана „социјална стратификација учесника у преписци“, те издвајање средњовјековних и модерних форми преписке (БЈЕлАКовић 2020:

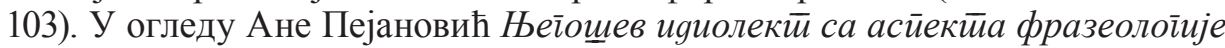
сагледане су особине Његошевог језика кроз однос његове фразеологије према фолклорној и народној фразеологији, а затим је указано на „прецедентни карактер Његошеве фразеологије“, на њен однос према разумијевању етнокултурне слике свијета. При томе је сагледана Његошева фразеологија из преспективе транслатологије, као и сагледавање те фразеологије као „грађе за израду првог фразеолошког рјечника писаца код нас“"(ПЕЈАновић 2020: 127).

5.4. Дијалекатски и морфосинтаксички приступ језику Његошевог дјела

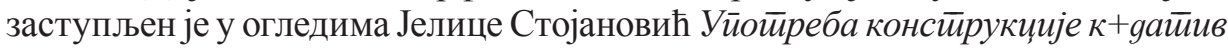
у Њеїощевом дјелу и Миодрага В. Јовановића Неке морфолощке и синйаксичке особине Горског вијенца у йоређењу са сйароирноіорским іоворима. Јелица Стојановић је истраживала функцију конструкције к+датив тако што је посматрала стање у праславенском језику, као и у дијалектима, а онда их упоредила са стањем код Његоша. Истражена грађа је показала да је конструкција к+датив у Његошевом дјелу била веома фреквентна и да се нарочито користила „Уз глаголе кретања“, а потом и као „допуна различитим врстама ријечи“ (СтоЈАновић 2020: 57). У огледу Миодрага Јовановића урађено је поређење Његошевих језичких карактеристика, као што су глаголске реакције и употреба инфинитива и конструкције да+презент, са циљем да се сагледа блискост Његошевог језика са „мјесним цетињско-његушким говорним типом“, као и са „Вуковим и Даничићевим моделом српског књижевног језика“" (ЈовАновић 2020: 171).

5.5. Посебну цјелину у четвртом броју Њеїощевог зборника Майице

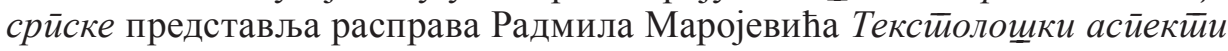
ирроучавања Њеїощевих дјела (крийичка, акиенайска и основна издања), која је заснована на непосредном приређивачком искуству приликом штампања појединих Његошевих дјела. У огледу је указано на особине „критичког“, „акценатског“ и „основног издања“ Његошевих дјела, а затим је на примјеру 
свог издања Његошеве епске трилогије (Луча микрокозма, Горски вијенаи, Лажни циар Шћейан Мали), као и пјесама из Биљежнице, те издања једине Његошеве сачуване љубавне пјесме пјесме Ноћ скуйља вијека, показана сва сложеност текстолошког приступа Његошевом дјелу. Односи се то прије свега на одабир адекватног корпуса текстова за критичко издање, на проблеме акценатског издања, као и на могуће приступе основном издању Његошевих дјела које би било усмјерено према најширој читалачкој публици. У посебном сегменту огледа, под насловом Текстиолойија, Маројевић је указао на главне карактеристике сва четири тома свог критичког издања Његошевих дјела, са посебним освртом на „проблеме ономастичке реконструкције“ (антропонима и топонима), „проблеме семантичке реконструкције“ (граматика, лексика, фразеологија), „проблеме фонетско-фонолошке реконструкције“ (сугласници, рефлекс јата), као и „проблеме реконструкције текста“ на плану његове изворности и аутентичности (МАРојевић 2020: 81-86).

6. На крају приказа можемо закључити да су четири објављена броја Њеїощевої зборника Майице срииске донијела један потпуно нов замах читању и тумачењу Његошевог дјела, те да су у њима на репрезентативан начин представљени различити аспекти тог дјела. Указано је на културолошке и компаративне аспекте дјела, на књижевноисторијске студије, историјско језичке аспекте, лексичке особености и потребу сталних лексикографских истраживања, текстолошке проблеме и начине приређивања, као и на рецепцију Његошевог дјела кроз сагледавање најважнијих студија које су написане о дјелу и пјесниковој личности код нас и у славистичким круговима у иностранству. Захваљујући свему томе представљени бројеви Њеїощево зборника Майице срйске отворили су разнолике и драгоцјене просторе истраживања који ће нам помоћи да још боље упознамо Његошево доба, дјело и личност. Упутиће нас да Његоша и његово вријеме адекватним знањем представимо савременим генерацијама читалаца, а самим тим и да га одбранимо од незнања, као и од могућих злонамјерних читања, фалсификата и тренутних ускогрудих политичких идеологија и злоупотреба.

\section{ЦИТИРАНА ЛИТЕРАТУРА}

БАБић, Душко Н. Песник метафизичког понора - Поводом књиге Мила Ломпара Њеіощево йеснищйво. Њеїощев зборник Майице срйске. 3. Нови Сад, 2018, 111-128. БЕћковић, Матија. Свети Петар II Петровић Његош пустињак цетињски. Њеїощев зборник Майице срйске. 3. Нови Сад, 2018, 23-30.

БЈелАковић, Исидора. Елементи славеносрпског у језику Његошевих писама. Њеі̄oщев зборник Мат̄ице срйске. 4. Нови Сад, 2020, 103-126.

Буловић, преосвећени епископ Иринеј. Поздравна реч Његовог преосвешстенства епископа бачког г. Иринеја. Њеїощев зборник Майице срйске. 1. Нови Сад, 2010, 11-14. 
Буловић, преосвећени епископ Иринеј (Буловић). За Његоша. Њеі̆омев зборник Майице срйске. 3. Нови Сад, 2018, 9-10.

Вуксановић, Миро. Реч на почетку. Њейощев зборник Майище срӣске. 1. Нови Сад, 2010, 7-8.

Вуксановић, Миро. С Његошем боље знамо. Њейощев зборник Майице срйске. 3. Нови Сад, 2018, 17-22.

Вуксановић, Миро. Његошев дан у Матици српској. Њейощев зборник Майище срйске. 4. Нови Сад, 2020, 7-10.

ВуксАновић, Миро. Треба нам свака Његошева реч (За ново издање Речника Њеі̆ощева језика). Њеїощев зборник Майице срйске. 4, Нови Сад, 2020a, 11-14.

Грковић-Мејџор, Јасмина. Језик обичајног права у Његошевим делима. Њеі̆омев зборник Майице срйске. 4. Нови Сад, 2020, 45-56.

Делић, Јован. Његош у виђењу Миодрага Павловића. Њеі̆ощев зборник Майице срӣске. 1. Нови Сад. 2010, 193-210.

ДЕлић, Јован. Матија Бећковић и Његош. Њеі̄ощев зборник Майиие срӣске. 2. Нови Сад, 2014, 297-320.

Ераковит, Радослав. Лик Сатане у Његошевој Лучи микрокозма и религиозним еповима српског предромантизма. Њеі̆ощев зборник Майице срӣске. 2. Нови Сад, 2014, 235-244.

ИвАнић, Душан. Његошеви аутопоетички искази у оквирима српске пјесничке традиције. Њейощев зборник Майице срӣске. 2. Нови Сад, 2014, 159-168.

Јелић, Војислав П. Све природа снабд’јева оружјем. Њейощев зборник Майице срйске. 3. Нови Сад, 2018, 273-280.

ЈовАновић, Миодраг В. Неке морфолошке и синтаксичке особине Горской вијенца у поређењу са староцрногорским говорима. Њейощев зборник Майице срйске. 4. Нови Сад, 2020, 171-188.

КовАчевић, Милош. Његошев однос према српском језику. Њеїощев зборник Майице срӣске. 2. Нови Сад, 2014, 169-180.

Кољевић, Светозар. О Његошевом надахнућу бесудном земљом, Њейомев зборник Майице срӣске, број 2, Нови Сад, 2014, 35-50.

Кнежевић, Микоња. Религија Његошева: скица за једну студију о религиозном промишљању Његошевог пјесништва владике Николаја Велимировића. Њеі̆омев зборник Майице срӣске. 3. Нови Сад, 2018, 59-76.

Ломпар, Мило. Аница Савић Ребац о Његошу. Њейомев зборник Майиие срйске. 3. Нови Сад, 2018, 181-194.

МАкуљевић, Ненад. Савременик, херој и светитељ: креирање Његошевог лика у визуелној култури. Њейощев зборник Майице срӣске. 2. Нови Сад, 2014, 511-528.

МАролевић, Радмило. Текстолошки аспекти проучавања Његошевих дјела (критичка, акценатска и основна издања). Њейощев зборник Майице срӣске. 4. Нови Сад, 2020, 69-90.

МАтовић, Веселин. Његош у црногорским уџбеницима за језик и књижевност. Њеіомев зборник Майице срӣске. 2. Нови Сад, 2014, 529-540. 
Милошевић-ЂорЂевић, Нада. О неколиким песмама у Његошевом Оїлеgалу срйском. Њеі̄ощев зборник Майице срӣске. 1. Нови Сад, 2010, 113-130.

МилАновић, Александар. Његош и славеносрпска традиција. Њеі̆ощев зборник Маииице срйске. 4. Нови Сад, 2020, 91-102.

Мићовић, преосвећени епископ Јоаникије. Царска порфира. Њеі̆омев зборник Маиимие срйске. 2. Нови Сад, 2014, 19-28.

Мршевић РАдовић, Драгана. Лав, гуска и петао (поводом једног Његошевог стиха). Њеїощев зборник Майице срйске. 1. Нови Сад, 2010, 103-112.

НЕгРишорАц, Иван. Рецепција Његошевог дела на страницама Матичиног Лет̄ойиса (1831-1852): прилози Теодора Павловића и Јована Суботића. Њеїомев зборник Майице срйске. 2. Нови Сад, 2014, 253-280.

Осолник, Владимир. Аутори српских, хрватских и словеначких историја књижевности о Његошевом Горском вијениу. Њеі̆ощев зборник Майице срйске. 2. Нови Сад, 2014, 477-488.

Остолић, Бранислав. Књижевни језик Петра II Петровића Његоша и Вуков модел књижевног језика. Њеі̄ощев зборник Майище срӣске. 1. Нови Сад, 2010, 95-102.

ПејАновић, Ана. Његошев идиолект са аспекта фразеологије. Њеіомев зборник Маииице срӣске. 4. Нови Сад, 2020, 127-160.

Перовић, Драго. О Њеі̄ощевој Лучи Слободана Томовића. Њеі̄ощев зборник Майище срйске. 3. Нови Сад, 2018, 257-272.

Попов, Чедомир. Поздравна реч председника Матице српске академика Чедомира Попова. Њейощев зборник Майице срӣске. 1. Нови Сад, 2010, 9-10.

РАдовић, преосвећени митрополит Амфилохије. Христоцентричност Престола свесвјетија по Његошу. Њейощев зборник Майице срӣске. 2. Нови Сад, 2014, 11-18.

РАдуловић, Милан. Стваралачки преображаји српских културних образаца у Његошевом пјесништву. Њеі̄ощев зборник Майище срӣске. 2. Нови Сад, 2014, 147-158.

РемЕтић, Слободан. Вук и Његош на стази богаћења лексичког фонда српског језика. Њеі̄ощев зборник Майице срйске. 2. Нови Сад, 2014, 79-88.

СтАнић, Драган. Његош и српска култура не могу се одвојити. Њейощев зборник Майице срйске. 3. Нови Сад, 2018,11-16.

Стевановић, Михаило. Сврха и начин израде овога дела (Предговор двотомном Речнику Њеі̄ощева gела, 1983). Њеі̄ощев зборник Майице срйске. 4. Нови Сад, 2020, 15-43.

СтолАновић, Јелица. Употреба конструкције к + датив у Његошевом дјелу. Њейомев зборник Майице срйске. 4. Нови Сад, 2020, 57-68.

ШијАковић, Богољуб. Христос у Његошевом дјелу. Њеі̄ощев зборник Майице срйске. 1. Нови Сад, 2010, 43-48. 
Goran M. Maksimović

NJEGOŠ'S WORK IN NJEGOŠ'S JOURNAL OF MATICA SRPSKA

\section{Sum mary}

The review was analyzed the contributions dedicated to the research of the literary work, ruling activities and personalities of Peter II Petrović Njegoš (1813-1851), which were published in four issues of Njegoš's journal of Matica srpska (1/2010, 2/2014, 3/2018, 4/2020). The contributions are analyzed typologically classified into theological-philosophical, historical, literary-historical, comparative, historical-linguistic, cultural, linguistic-stylistic and textual essays. It has been shown that they are the presented essays opened methodologically diverse spaces research that helps us to Njegoš's age, work and personality we look at it from a contemporary perspective.

\section{Др Горан М. Максимовић}

Одсек за србистику

Филозофски факултет

Универзитет у Нишу

goran.maksimovic@filfak.ni.ac.rs 